Rabaska

Revue d'ethnologie de l'Amérique française

\title{
Coffret Notre-Dame de Québec 1664-2014
}

Volume 14, 2016

URI : https://id.erudit.org/iderudit/1037454ar

DOI : https://doi.org/10.7202/1037454ar

Aller au sommaire du numéro

Éditeur(s)

Société québécoise d'ethnologie

ISSN

1703-7433 (imprimé)

1916-7350 (numérique)

Découvrir la revue

Citer ce document

(2016). Coffret Notre-Dame de Québec 1664-2014. Rabaska, 14, 171-171.

https://doi.org/10.7202/1037454ar

Ce document est protégé par la loi sur le droit d'auteur. L'utilisation des services d'Érudit (y compris la reproduction) est assujettie à sa politique d'utilisation que vous pouvez consulter en ligne.

https://apropos.erudit.org/fr/usagers/politique-dutilisation/
Cet article est diffusé et préservé par Érudit.

Érudit est un consortium interuniversitaire sans but lucratif composé de l'Université de Montréal, l'Université Laval et l'Université du Québec à Montréal. Il a pour mission la promotion et la valorisation de la recherche. https://www.erudit.org/fr/ 


\section{Place publique}

Points de vue / livres

\section{Coffret Notre-Dame de Québec 1664-2014}

En 2014, la paroisse Notre-Dame de Québec fêtait son $350^{\circledR}$ anniversaire de fondation. Pour marquer l'événement, divers projets à caractères religieux et patrimoniaux ont vu le jour et permis à la capitale de voir son tourisme religieux augmenter de près de $40 \%$ en un an, grâce surtout à l'inauguration d'une porte sainte à la basilique-cathédrale Notre-Dame de Québec, première à être érigée en-dehors de l'Europe, privilège accordé par le Saint-Siège à la première paroisse catholique d'Amérique du Nord située au nord des territoires espagnols. Et pour rendre un hommage plus durable à l'histoire de la

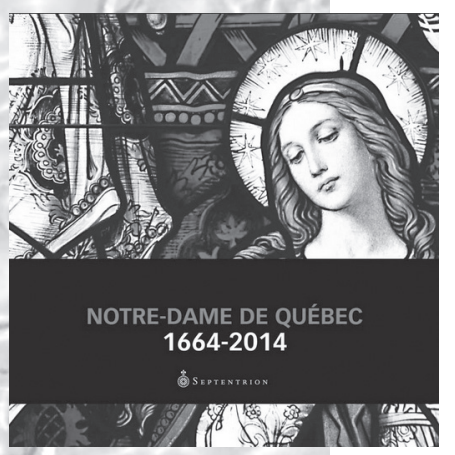

paroisse et à son patrimoine artistique, cinq auteurs ont été invités à créer une collection d'autant d'ouvrages totalisant plus de mille pages et ornés de 500 illustrations couleur. Rabaska a demandé à trois spécialistes d'exprimer leur point de vue sur le cadeau d'anniversaire que s'est offert la paroisse fondée en 1664 par François de Laval. David Mendel est historien de l'architecture et président-fondateur des Visites Mendel, entreprise œuvrant en tourisme culturel.

Ginette Laroche est pour sa part historienne de l'art spécialisée dans le champ religieux. Sophie Duhem, notre invitée d'outre-mer, est maître de conférences en histoire de l'art moderne à l'Université de Toulouse II - Le Mirail.

Jean-Marie Lebel (dir.), Coffret Notre-Dame de Québec 1664-2014, Québec, Septentrion, 2014, 5 vol., 1089 p. ill.

ISBN 9782894487877. 